significance - that it counts for nothing more than the antiballistic missile treaty, now threatened by the star wars programme. The assumption that these documents count for nothing is a psychological mistake. The most striking evidence to the contrary is that the two superpowers, while knowing that the treaties lack the force of law, have nevertheless chosen to behave as if the traties were binding on them. But to the extent that the states of Wistern Europe are interested parties, these scraps of paper are the only assurance they have that events will not get out of hand.

It would serve Mr Perle's purpose just as well, and that of the US administration at the same time, if he were to turn the other cheek and challenge the Soviet Union by demanding that the US Congress should ratify the threshold test-ban treaty in its present form, which forbids the testing even underground of nuclear warheads exceeding the equivalent of 150,000 tonnes of TNT. This, broadly speaking, is the practice to which the superpowers have kept since 1972. Congress in its present mood would sign with very little persuasion. (Only the Senate would matter.) The benefits would be that the Soviet Union would be required to produce a stack of seismic data with the help of which suggestions of violations could be more accurately assessed, even retrospectively. If Mr Perle's suspicions are correct, they would be confirmed. If they are not, sweetness and light would spread. Either way, the fear would be dispelled that the US administration is divided on arms control, showing up at Geneva diligently while thinking like Mr Perle.

\section{Football squalor}

\section{The deaths at a British football game should be an invitation to economic realism.}

THE British government is in a tragic dilemma over the game of soccer, otherwise association football. Last Saturday, 53 people were killed (with more than a dozen people still missing) when a wooden structure in which several thousand had been sitting caught fire and burned to a cinder in the Yorkshire city of Bradford. But for most of the winter, the government has been worrying not simply about the British economy but about the phenomenon of soccer hooliganism, the way in which bands of football supporters attack each other, or the other side's players, or sometimes the officials who try to ensure fair play. Football crowds have been a worry for British governments ever since 1972, when even more people were killed than last weekend during a stampede at a football ground in Glasgow.

The causes of last weekend's fire and of the long-standing hooliganism of football crowds are linked. British professional football, long since a spectator sport, is by legend the poor man's entertainment. So it was before the invention of the television, since when attendance at football matches has been falling steadily. Now, it is more accurately a poor professional's living. All but the best of football teams scrape by on a shoestring. Their grounds are squalid places. Sitting room is limited and expensive. Most have to stand for a couple of hours at a stretch, often crowded together in a way almost calculated to provoke violence. Yet so parlous is their financial condition that more than a third of the football grounds in England and Wales have been exempted from the safety regulations made law in 1975.

The simple question prompted by the death of 53 people in a tinderbox is whether it makes sense for a British government which has other things to worry about to shelter from economic reality commercial organizations which cannot afford to protect their customers from avoidable risks, let alone provide them with an environment which induces them to watch the game and not attack each other. Whether a country of 50 million people needs more than 100 professional football teams in the top flight (counting those in Scotland) is a matter that should be determined by market forces and not the government. If the outcome were that some were at a loose end on Saturday afternoons, and forced as a consequence actually to play the game they would otherwise be watching, that might be no bad thing.

\section{Patent rights}

Two years late, British academics are to have title to patents arising from inventions.

Two years have passed since the British Prime Minister, Mrs Margaret Thatcher, promised publicly that inventions generated with public support would no longer have to be offered for exploitation to the National Research Development Corporation (NRDC), but only this week has the government decided that the time for changing the present system has actually arrived. From now on, universities will be free to exploit their own inventions, whether or not they arise from research grants awarded from public funds. NRDC will remain in being (as part of what is now called the National Enterprise Board), and may paradoxically be even more ready in the future than in the past to exploit inventions offered by academic researchers, not least because there will be competition. Individual researchers are likely to be excited (and surprised) by the details of the new arrangements, which should provide them with a powerful incentive to market their discoveries, but their institutions will also benefit, on paper at least. So will British academic research now be further transformed by people's ambitions to get rich?

To a first approximation, the answer is no. The new arrangements for the exploitation of British inventions are no different in principle from those in force in the United States since 1972. Before British academic researchers and their institutions start counting their golden geese (to mix two metaphors), they had better reflect on the frequently disappointing experience of US universities, which have often found that the right to the independent exploitation of innovations is often exercised only with difficulty, while the duty to do so (implied by the US legislation) may be onerous. For what many US universities have discovered is largely what NRDC has been saying almost since its foundation in 1947 - that only a tiny proportion of academically-based patents become money-spinners. A large national organization, with a monopoly right of first refusal, can hope to cover the cost of protecting ideas taken onto its books by the proceeds from a few money-spinners. Smaller organizations, even whole universities, are by definition less able to cover their risks.

Even so, it is right that there should be a change in the arrangements in force in Britain. Although NRDC has never managed to demonstrate the touching belief of its founders that $\mathrm{Bri}$ tain was awash with patentable inventions going to waste, and while its work over the decades has been creditable, it has also accumulated a rich fund of ill-will among academic researchers who consider, rightiy or wrongly, that their bright ideas have been too often overlooked. The truth, of course, is that no single organization can hope to make consistently wise decisions in such a vast field. The best approach is bound to be one in which different organizations make independent appraisals of novel developments and then agree to back those they fancy with tangible resources, both money and management. With the persistent pressure on university research funds, and the change in general attitudes towards the exploitation of new ideas, ending the corporation's monopoly right will do much more good than harm.

The consequences of this change for the character of what happens in British academic laboratories is unlikely, in the short run, to be profound. To be an acknowledged success as a scientist or engineer will continue to be an important if no longer a paramount consideration. Moreover, NRDC will retain an active interest, and indeed is plainly planning (with government help) to strengthen its links with university researchers. The most likely change is that there will be other venture capitalists scouring the academic laboratories for exploitable innovations, while established companies will have a further incentive to forge academic links, perhaps with particular departments, by offering help with patent protection. The danger, probably not at this stage serious, is that some universities or parts of them may become so immured in particular relationships that they will cease to be impartial sources of help and advice for industry at large. That is an issue to which university administration should urgently pay attention. 